\title{
肛門括約筋内結腸瘦を併用せる直腸膀胱術
}

\author{
II 自験症例の成績とその検討 \\ 柏并浩 三 \\ 大阪厚生年金病院泌尿器科 \\ 高橋香司 \\ 松田稔 \\ 坂口強 \\ 神戸大学医学部泌尿器科教室 石 神裏 次

\section{URINARY DIVERSION： RECTAL BLADDER COMBINED WITH INTRASPHINCTERIC PERINEAL COLOSTOMY} \\ II. Clinical Studies on 44 Cases \\ Kozo Kashiwai, Koji Takahashi, Minoru Matsuda and Tsuyoshi Sakaguchi \\ Department of Urology, Osaka Welfare Pension Hospital \\ Joji Ishigami \\ Department of Urology, Kobe Univercity Medical School
}

Forty-four patients underwent an operation for rectal bladder combined with intrasphincteric perineal colostomy during the past 8 years. Of these, 20 were operated by Lowsley-Johnson procedure, 11 by Staehler's, 12 by Duhamel-Boissonnat procedure, and the remaining one by Heitz-Boyer Hovelacque procedure.

Thirty-seven patients had a malignant disease.

The results are given below.

1) Early mortality (within 30 days of operation) was $6.8 \%$ (3 cases), and late mortality (beyond 30 days) was $22.7 \%$ (10 cases). The latter was always due to carcinomatosis.

2) The most frequent complication that had developed in both early and late postoperative courses was pyelonephritis. Hyperchloremic acidosis with manifest clinical signs was noted in 3 patients $(7.3 \%)$ and was transient.

3) Three different techniques mentioned in our preceding paper were used for ureteral implantation, and the results of these three were compared one another. Patients were followed by periodic excretory urography (IVP) and retrograde rectosigmoidography. The findings in this study suggest that the cause of upper urinary tract infections after construction of an isolated rectosigmoid bladder is urinary stasis due to stricture of the ureter at the anastomosed site, rather than intestino-ureteral reflux. Accordingly, the authors believe that mucosa-to-mucosa anastomosis is the most reliable technique for ureteral implantation.

4) Urination in the postoperative course was nearly satisfactory, but bed wetting was recorded in 18 cases $(51.5 \%)$, including $5(15.2 \%)$ who suffered every night, of the 35 patients who were successfully followed up.

5) Restoration of defecating function was described. From the point of view of this function, the "retroanal (-rectal) sigmoid pull through" is advantageous over other techniques. In pulling through the sigmoid colon, one must pay attention not to damage the puborectal sling.

6) One half the patients undergoing this operation returned to preoperative activities. Of these, all the patients with benign disease returned succesfully to their work. 
肛門括約筋内結腸㜢を併用せる直腸膀胱術について， 第 1 篇では，筆者らが行なつた手術手技の要点と，この 手術に残されている問題点を述べた。ここでは1965年以 来, 過去 8 年間に筆者らが経験した症例の成績を述べ, さらに，それらの成績について検討を加えたい。

\section{自験症例}

尿䔬の禁制保持に肛門括約筋を利用する尿路变向術に ついて，筆者らが経験した症例は尿䔬混合型が14例，尿 翼分離型が55例である．尿䔬分離型のらち肛門括約筋内 結腸瘦 (intrasphincteric sigmoid pull through) を併用し た手術例は44例になる（表 1）.44例を術式別にみると，

表 1 Rectosigmoid bladder with anal sphincter control

Technıque employed (Nov.1965 June 1973)

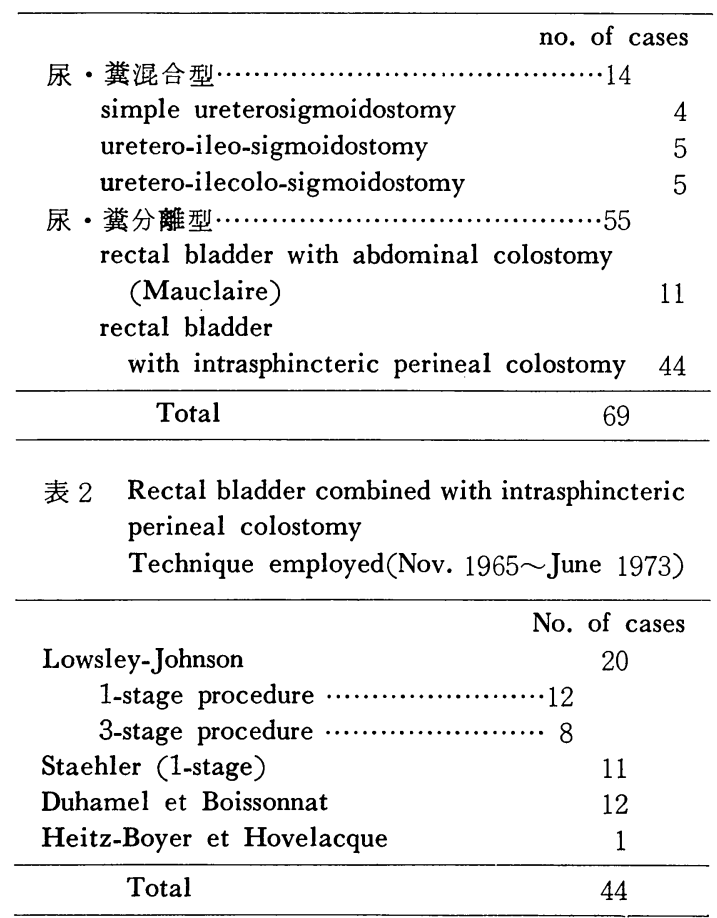

Lowsley-Johnson手術20例, Staehler 手術11例, DuhamelBoissonnat 手術12例, Heitz-Boyer Hovelacque 手術 1 例である (表 2). Lowsley-Johnson 手術20例のらち, 8 例は手術操作を Staehler 法1)にならつて 3 stages（横行 結腸瘦造設 $\rightarrow$ 直腸膀脂形成 $\rightarrow$ 横行結腸瘦閉鎖）飞行なつ た. その他の症例は過剩 $\mathrm{S}$ 状結腸の切除をのぞいて,す べて one-stage で行なつた． 年令は12才より72才，男 38 例, 女 6 例である. 適応疾患は悪性疾患 37 例, 良性疾
表 3 Indication for operation

\begin{tabular}{l|lr|c}
\hline & \multicolumn{3}{|c}{ Number of cases } \\
\hline malignant & $\begin{array}{l}\text { Bladder cancer } \\
\text { Prostatic cancer }\end{array}$ & 36 & 37 \\
\hline benign & $\begin{array}{l}\text { Intractable urethral stricture } \\
\text { Intractable vesico-vaginal fistula } \\
\text { Contracted bladder with } \\
\text { sphincter incontinence }\end{array}$ & 1 & 7 \\
\hline & \multicolumn{2}{c|}{ Total } & 1 \\
\hline
\end{tabular}

患 7 例である（表 3 ).なお，follow up の期間は 6 力月 より 7 年 7 カ月におよぶ.

\section{成 績}

\section{1. 術後死亡}

手術死亡（術後 1 カ月以内に死亡したものを手術死と みなした）は 3 例であつた. 3 例とも膀羘腫痬に対して 膀脱全摘除術を併用したものであつて，良性疾患 7 例中 には手術死はない，それゆえ全症例に対する手術死亡率 は $6.8 \%$ ，覀性疾患の症例に対する手術死亡率は $8.1 \%$ となる. 手術死亡の原因は急性腎不全 2 例, 腹膜炎 1 例 で, 腹膜炎の症例は pull through した $\mathrm{S}$ 状結腸壁の壊死 によるもので, 術後 8 日目, 壊死部の結腸を切除し, Mauclaire 手術に変え, 腹腔内のドレナージを行なつた が助けられなかつたものである.

術後 1 カ月以後の死亡は10例を数えるが，いづれも膀 脱腫瘳の転移, 再発によるものであつた. それらの術後 生存期間は 4 力月より 5 年におよぶ. 他方, 良性疾患に は死亡者はなく，7例すべて健康状態を保ち，社会復帰 を果している（表4）.

\section{表 4 Mortality}

\begin{tabular}{l|c|c}
\hline & early & late \\
\hline benign & $0 / 7(0 \%)$ & $0 / 7(0 \%)$ \\
malignant & $3 / 37(8.1 \%)$ & $10 / 37(27.0 \%)$ \\
\hline \multicolumn{1}{c|}{ total } & $3 / 44(6.8 \%)$ & $10 / 44(22.7 \%)$ \\
\hline
\end{tabular}

\section{2. 術後合併症}

術後 1 カ月以内に発生した合併症を早期合併症 (early complications), 1 力月以後のものを晚期合併症 (late complications）とし，それぞれ表 5（A，B）,表 6 に示 した.

何らかの早期合併症をおこした症例は44例中22例 
裴 5-A Early complications

\begin{tabular}{|c|c|c|c|c|}
\hline $\begin{array}{c}\text { Techniques \& } \\
\text { no. of cases }\end{array}$ & 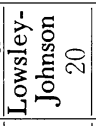 & 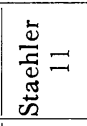 & 离 & 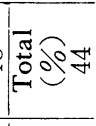 \\
\hline Acute pyelonephritis & 7 & 3 & 5 & $\begin{array}{c}15 \\
(34.1)\end{array}$ \\
\hline Wound dehiscence & 3 & 0 & 0 & 3 \\
\hline Wound infection & 3 & 0 & 0 & 3 \\
\hline Temporary anuria & 2 & 0 & 1 & 3 \\
\hline Acute renal failure & 2 & 0 & 0 & 2 \\
\hline $\begin{array}{l}\text { Uretero-intestinal } \\
\text { obstruction } \\
\text { (requred reimplantation) }\end{array}$ & 0 & 0 & 1 & 1 \\
\hline Peritonitis & 0 & 0 & 1 & 1 \\
\hline $\begin{array}{l}\text { Retroperitoneal } \\
\text { hematoma }\end{array}$ & 0 & 1 & 0 & 1 \\
\hline Pulmonary edema & 0 & 0 & 1 & 1 \\
\hline No complications & $\begin{array}{c}9 \\
(45.0)\end{array}$ & $\begin{array}{c}8 \\
(72.3)\end{array}$ & $\begin{array}{c}5 \\
(38.5)\end{array}$ & $\begin{array}{c}22 \\
(50.0) \\
\end{array}$ \\
\hline
\end{tabular}

* Heitz-Boyer et Hovelacque operation 1 例を含む

表 5-B Staged procedure and early complications

\begin{tabular}{l|c|c}
\hline \multirow{2}{*}{} & \multicolumn{2}{|c}{ Lowsley-Johnson operation } \\
\cline { 2 - 3 } & 1-stage & 3-stage \\
\hline $\begin{array}{l}\text { No. of patients } \\
\text { Cases with early } \\
\text { complications (\%) }\end{array}$ & $\begin{array}{r}8 \\
(66.7 \%)\end{array}$ & $\begin{array}{c}3 \\
(37.5 \%)\end{array}$ \\
\hline
\end{tabular}

(50.0\%)である. その主なるものは acute pyelonephritis 15例 $(34.1 \%)$ で, そのほか, wound dehiscence, wound infection, temporary anuria などがみられる. 手術死 に直接つながつた合併症は，前述のように acute renal failure と peritonitis であつた. temporary anuria は尿管 吻合部の一過性浮腫が原因と考えられ，そのうち 2 例は 無尿発現後48時間以内に緩解した. 他の 1 例はそれ以上 に続いたため一側の一時的腎㾇術を施行した。これら 3 症例とも, その後の IVP では全く正常に復している.

晚期合併症については，41例中31例（75.6\%）に何ら かの合併症がみられた（表6). recurrent pyelonephritis とは 1 年に 3 回以上の発熱発作をくりかえしたもので,

6 例 $(14.6 \%)$ を数えた。これに，1 年間にたとえ 1 回 でも acute pyelonephritis と思われる発熱をみた症例を 加えると16例になり，この点について follow up できた 症例36例中の $44.4 \%$ にある。年の他，比較的多いもの では慢性便秘（常に下剂を必要とするもの）, pelvic abs-
表 6 Late complications

\begin{tabular}{|c|c|c|c|c|}
\hline $\begin{array}{c}\text { Techniques \& } \\
\text { no. of cases }\end{array}$ & 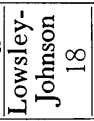 & 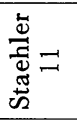 & 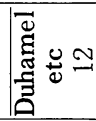 & ॠँ \\
\hline Recurrent pyelonephritis & 2 & 1 & 3 & $\begin{array}{c}6 \\
(14.6)\end{array}$ \\
\hline Pelvic abscess & 4 & 1 & 0 & 5 \\
\hline Pyocystis & 1 & 1 & 0 & 2 \\
\hline Intestinal obstruction & 0 & 2 & 1 & 3 \\
\hline Constipation & 2 & 3 & 1 & 6 \\
\hline Fecal fistula & 1 & 0 & 0 & 1 \\
\hline Stenosis of sigmoid stump & 1 & 0 & 0 & 1 \\
\hline Carcinoma in wound & 1 & 0 & 1 & 2 \\
\hline $\begin{array}{l}\text { Acidosis required } \\
\text { alkalinization }\end{array}$ & 1 & 1 & 1 & $\begin{array}{c}3 \\
(7.3)\end{array}$ \\
\hline $\begin{array}{l}\text { Bilateral progressive } \\
\text { hydronephrosis }\end{array}$ & 1 & 0 & 0 & 1 \\
\hline Serum hepatitis & 2 & 2 & 1 & 5 \\
\hline Melena & 1 & 0 & 0 & 1 \\
\hline No complications & 4 & 3 & 3 & $\mid \begin{array}{c}10 \\
(24.4)\end{array}$ \\
\hline
\end{tabular}

表 7 Complications of new anus

\begin{tabular}{|c|c|c|c|c|}
\hline $\begin{array}{c}\text { Techniques \& } \\
\text { no. of cases }\end{array}$ & 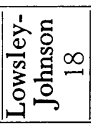 & 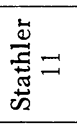 & 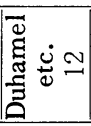 & $\stackrel{\vec{\pi}}{0}=$ \\
\hline Septal retraction & 4 & 2 & 3 & 9 \\
\hline Stricture of new anus & 2 & 1 & 1 & 4 \\
\hline Mucosal extroflexion & 2 & 0 & 2 & 4 \\
\hline Prolapse through new anus & 2 & 0 & 0 & 2 \\
\hline $\begin{array}{l}\text { Perianal dermatitis } \\
\text { (recurrent) }\end{array}$ & 3 & 0 & 1 & 4 \\
\hline
\end{tabular}

cess, serum hepatitis などがあげられる. hyperchloremic acidosis（低K血症を伴う）については, 全身脱力感, 食思不振, 覀心など明らかな臨床症状を呈したものは3 例 $(7.3 \%)$ で，何れもアルカリ剂投与により軽快し た。

新しく造設された肛門（会陰部結腸瘦）の合併症では septal retraction が最も多い。これは括約筋内における 尿路と翼路との隔壁が内方に引き込をれた状態を云う。 その他, 新肛門の狭窄 (septal retractionを伴なうこ とが多い), mucosal extroflexion, perianal dermatitis, sigmoid prolapse がみられた（表 7 ）.

術後合併症の発生頻度を術式別にみると, 早期合併症 において各術式間に多少の差がみられるほか, 特に有意 の差はなかつた。 
表 8 Operations required for complications

\begin{tabular}{l|c}
\hline & $\begin{array}{c}\text { Number } \\
\text { of cases }\end{array}$ \\
\hline Nephrostomy & 1 \\
Ureteral reimplantation & 1 \\
Cutaneous ureterostomy & 1 \\
Descomps operation* & 1 \\
Sigmoid resection and abdominal colostomy & 1 \\
Lysis of ileal adhesion & 1 \\
Permanent cystostomy for pyocystis & 2 \\
Dehiscence repair & 3 \\
Incision and drainage retroperitoneal & 1 \\
Resection of prolapsed colon & 2 \\
Removal of extroflexed mucosa & 2 \\
\hline \multicolumn{1}{c|}{ Total } & 16 \\
\hline
\end{tabular}

* Hinman, F. and Weyrauch, H.: Intern. Abstr. Surg., $64: 313,1937$.

Lowsley-Johnson 手術のらち 1 stage で行なつた12例と 3-stage で行なつた 8 例では，早期合併症発生率がそれ ぞれ66.7\%と37.5\%となり，この成績のみからは3-stage procedure で合併症発生率が低いことを示す (図 5-B) しかし，他方において 1-stage で行なつた Staehler 手 術の早期合併症発生率は $27.7 \%$ であり，この点について 明らかな結論はでない。

新肛門の合併症では，その発生率は Lowsley-Johnson 手術に打いて, やや多い.

なお，以上の合併症により何らかの外科的治療を要し たものは16件で, その詳細を表 8 に示した.

3. 尿管移植術の成績

空置直腸 S 状結腸への尿管移植術として筆者らが用い た術式は，なでに第 1 篇でその要点を述べた，尿管移植 術の成績については, IVP と逆行性直腸造影 (ureteral reflux をみるため) を施行して検討した．IVP は術後 1 カ月， 3 カ月， 6 カ月，前後 6 カ月の間隔で行なつた.

（1）IVP による成績判定の基準

IVP 所見により，各術式の成績を比較，検討する場 合，判定基準が問題になる。一般に造影剂の腎からの排 泄時間により腎機能を推測 し，腎盂腎杯尿管の 形態か ら上部尿路の拡張度をみて，それぞれ $\mathrm{A} ， \mathrm{~B}, \mathrm{C}, \mathrm{D}, \mathrm{E}$; Grade 1，2，3，4，5などと段階的に分け，両者を組 合わせて判定する方法がとられている ${ }^{23)}$. しかし，造 影剤の排泄状態は同一個体とい吕どもいろいろな撮影条
件の差により変動がみられるほか，IVP から腎機能を 判定するのは明らかに限界があり，また，上部尿路の拡 張程度も判定者の主観に左右されることが多く，このよ うな細かい基準の設定には問題がある，筆者らは IVP 所見を，袎能と形態の両面を加味して評価を簡明にし， 以下のように 3 段階に分けた.

good……術前正常のものが，術後も正常のもの 術前異常のものが術後改善されたもの

fair ……術前・術後を通じて不変のもの

poor …....術後に悪化したもの

成績判定の時期は少なくとも 6 カ月を経過したものと なし，6 カ月以後のものでは，なるべく最近のものを採 用した。

（2）術後 IVP の推移

術後 6 カ月以上追跡できたものは40例76尿管（尿管移 植施行回数77）であり，その成績を表 9 に示した，筆 者らの用いた基準によれば good 55.8\%，fair 15.6\%， poor $28.6 \%$ となる．悪化率よりそれぞれの吻合術式の成

表 9 Radiography status

\begin{tabular}{|c|c|c|c|c|c|c|}
\hline $\begin{array}{l}\text { Techniques } \\
\text { for Uretero- } \\
\text { intestinal } \\
\text { anastomosis }\end{array}$ & 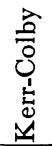 & 离 & 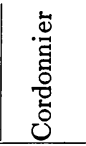 & $\frac{1}{3}$ & $\sum_{i=1}^{*}$ & 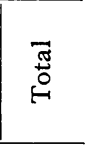 \\
\hline $\begin{array}{l}\text { No. of } \\
\text { ureters }\end{array}$ & 5 & 2 & $\begin{array}{c}12 \\
(\%) \\
\end{array}$ & $\begin{array}{c}19 \\
(\%) \\
\end{array}$ & $\begin{array}{c}39 \\
(\%) \\
\end{array}$ & $\begin{array}{c}77 \\
(\%) \\
\end{array}$ \\
\hline good & 0 & 0 & $\begin{array}{c}7 \\
(58.3) \\
\end{array}$ & $\begin{array}{c}14 \\
(73.7) \\
\end{array}$ & $\begin{array}{c}22 \\
(56.4) \\
\end{array}$ & $\begin{array}{c}43 \\
(55.8) \\
\end{array}$ \\
\hline fair & 3 & 2 & $\begin{array}{c}4 \\
(33.3) \\
\end{array}$ & $\begin{array}{c}1 \\
(5.3) \\
\end{array}$ & $\begin{array}{c}2 \\
(5.1) \\
\end{array}$ & $\begin{array}{c}12 \\
(15.6) \\
\end{array}$ \\
\hline poor & 2 & 0 & $\begin{array}{c}1 \\
(8.3) \\
\end{array}$ & $\begin{array}{c}4 \\
(21.0) \\
\end{array}$ & $\begin{array}{c}15 \\
(38.5) \\
\end{array}$ & $\begin{array}{r}22 \\
(28.6) \\
\end{array}$ \\
\hline \multirow{2}{*}{ Reflux } & 4 & 0 & 8 & 18 & 37 & \\
\hline & 1 & 2 & 4 & 1 & 2 & \\
\hline
\end{tabular}

* Sero-muscular folding technique

積を比較すると Cordonnier 法が $8.3 \%$ で最もよく, 以 下, Goodwin 法, Seromuscular folding 法の順であつ た. Kerr-Colby 法, Warwick nipple 法怯吻合施行回数 が少く比較できない，ただ Kerr-Colby 法で行なつた 5 尿管のらち good と判定できたものは1例むなからた。

（3）腸・尿管逆流現象

逆行性の直腸造影により腸尿管逆流の有無をみたが， その発生頻度については Cordonnier 法が高く, Goodwin 法, Seromuscular folding 法では低率で，後二者の吻合 術式では充分な逆流防止効果を認めた。

次にこれらのレ線学的所見と術後の急性腎孟腎炎発症 
図 1 Relationship between radiography status and pyelonephritis

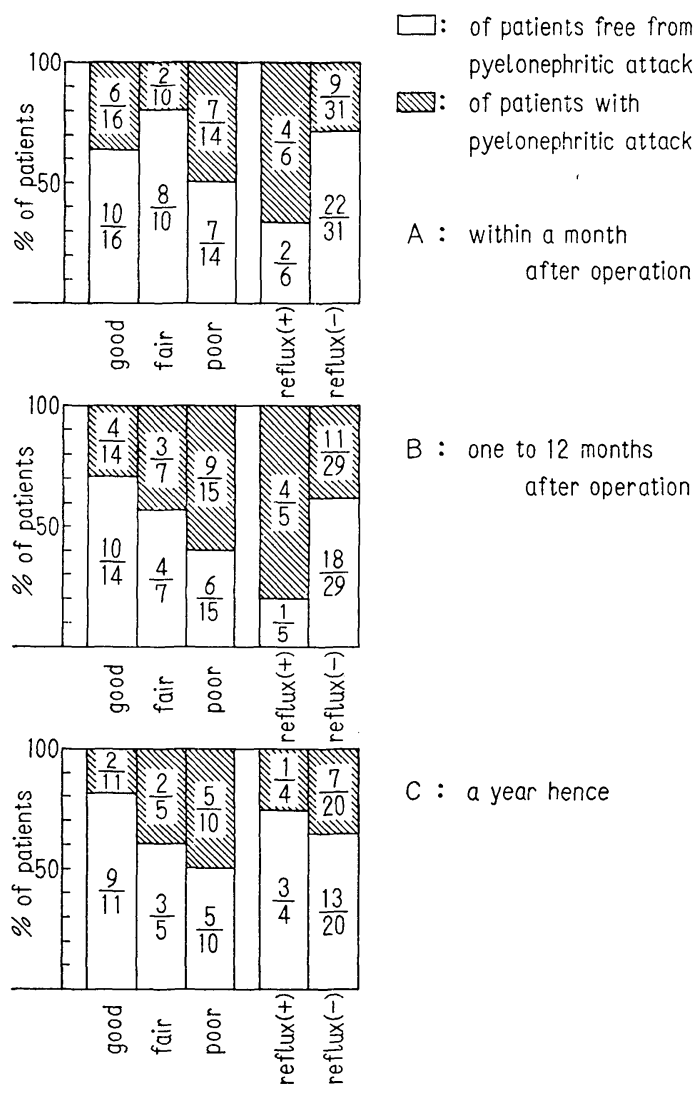

の有無との関係を図 $1 \mathrm{~A}, \mathrm{~B}, \mathrm{C}$ 示した. 術後のIVP が poor であつた場合，その約50\%は術後 1 力月を過ぎ ても，1回またはそれ以上の発熱発作（急性腎孟腎炎 による）に襲われる. 逆汪, good の場合は術後 1 力月 以後では，その70\%ないし80\%が何らの発熱発作をみ ない，このように術後 1 力月を過ぎると，IVP の成緽 の差が，そのまま急性腎孟腎炎発生の有無に影響する。 他方, 腸尿管逆流との関俰をみると, 術後 1 年までは明 らかに逆流の無い群は発熱発作が少ないが，1年以後の ものでは, 発熱発作の有無は, 逆流とは無関係になつて いる（図 1，C）.

4. 術後の腎機能

術後の腎機能の推移, 血液電解質值, 酸塩基平衝など については，直腸膀胱術の検討すべき問題の 1 つであ る. その詳細は次篇にゆゔるので,ここでは術前後の BUN と creatinineについて述べる. 術前後ともに測定，
表10 Creatinine and BUN

\begin{tabular}{llc}
\hline & \multicolumn{2}{c}{ Number of cases $(\%)$} \\
\hline Creatinine & Normal & 28 \\
& Elevated & $3(9.7 \%)$ \\
BUN & Normal & 33 \\
& Elevated & $4(10.8 \%)$ \\
\hline
\end{tabular}

追跡できたものは BUN37例, creatinine31例であつた。 このらち術後（6 カ月後）に異常値を示したものはBUN 4 例 $(10.8 \%)$, creatinine 3 例 $(9.7 \%)$ であつた（表 10) .

\section{5. 術後の排尿機能}

直腸膀腃に留置せるシリコンチューブの抜去後，一定 の頻尿期（1 力月〜 3 力月）を経て，尿回数は固定化す る. その回数は直腸膀胱の容量により異なるが，通常 昼間 5 回 12回, 夜間 1 回 5 回である. 直腸膀胱の容 量は $150 \mathrm{ml} \sim 400 \mathrm{ml}$ で, 残尿は $0 \mathrm{ml} \sim 30 \mathrm{ml}$ である. 一部の症例で排尿圧を測定したが，最高排尿圧は $40 \mathrm{~mm} \mathrm{Hg}$ 〜 70 mmHgを記録した。

尿の禁制保持については，follow up できた症例33例 のらち1例が失禁を示し，他はすべて完全に禁制を得て いる。この 1 例は術前すでに括約筋不全（痔瘦の根治手 術後の瘦痕形成のため) を有していたもので，手術適応 のあやまりと見なされる。なお，術後に夜尿を訴えたも のは33例中17例 $(51.5 \%)$ ，そのらち5例 $(15.2 \%)$ は連 日夜尿を訴えている。

表11 Function of rectosigmoid bladder

\begin{tabular}{|c|c|c|c|c|c|}
\hline & & 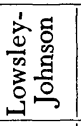 & 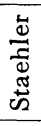 & 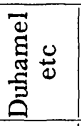 & $\begin{array}{l}\vec{J} \\
\stackrel{0}{0}\end{array}$ \\
\hline & & 13 & 10 & 12 & 35 \\
\hline \multirow{2}{*}{$\begin{array}{l}\text { Urinary } \\
\text { continence }\end{array}$} & complete & 12 & 10 & 12 & 34 \\
\hline & incomplete & 1 & 0 & 0 & 1 \\
\hline \multirow{2}{*}{ Bed-wetting } & - & 8 & 3 & 7 & 18 \\
\hline & + & $5(3)$ & 7 & $5(2)$ & $17(5)^{*}$ \\
\hline
\end{tabular}

* ( ) Enuresis at every night

これら排尿機能を術式別にみたものが表11である。こ れによると各術式間において排尿機能の上では特に差は 認めなかつた，術後の排尿愁訴としては，夜尿症のほか に排尿時不快(tenesmus) と二段排尿 (pis en doux temp) の各 1 例をみとめた。 
図 3 Angulation at the new ano-rectal junction

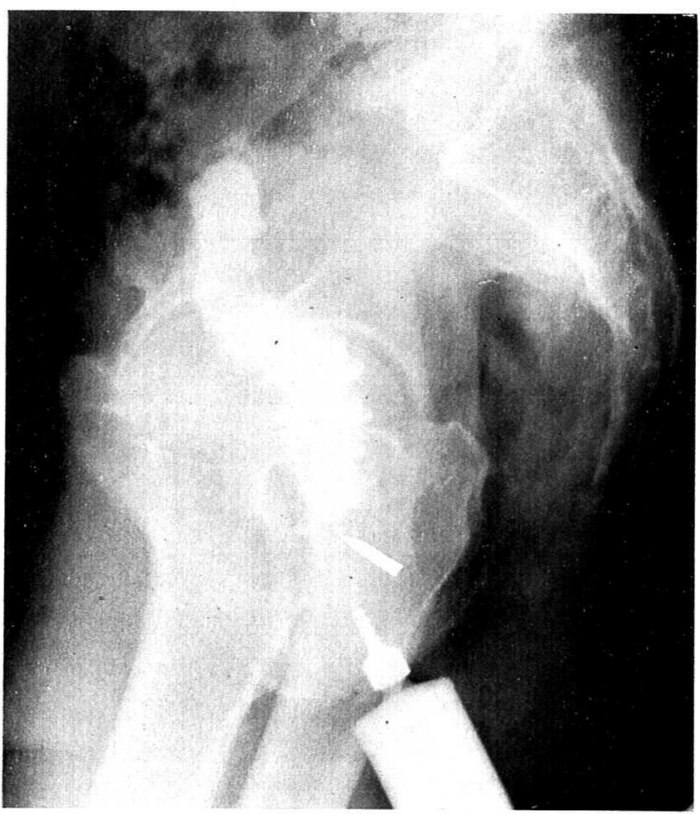

Retrograde ano-rectogram, lateral view M.H. 50才, 今 Duhamel-Boissonnat 手術, 術後: Angulation （矢印）は明瞭で, 肛門管は造影され難い。

注腸による新しい肛門ならびに下部結腸の造影では, 新肛門管の頭側端と思われる部分に，一種の “くびれ” angulationを認めた。一般に, 排便機能良好なるのほ ぞ,この angulation がはつさり描出されている（図 3).

\section{7. 術後の社会復帰}

尿路変问術後のみならず, 他の手術でも, 術後患者の 社会復帰については, 適応された患者の年令, 性, 疾患 (とくに悪性疾患か否か), 原職の種別など多くの因子に 左右されるので, これを一元的にとり扱らには無理があ る. しかし筆者らはこの尿路変向手術が術後のより完全 な社会復帰を目ざす術式である点を考光, あえて，この 点について調査した，follow up できた症例は44例中30 例でこれる表15に示した。これによれば退院した患者 の半数が原職に復帰 (婦人の場合は発病前と同等の労 働)していた。このほか軽作業に転じたものが $26.7 \%$, 労務不能のため休職しているものが $23.3 \%$ 認められた. なお，原疾患が良性のもの（尿道狭窄など）については 7 例中全例が元の職業に戻つたことをつけ加完たい。

考按

尿・穓ともにその禁制を保持する目的で行なわれるこ
表15 家庭に山ける生活情況（1973年 6 月現在）

\begin{tabular}{|c|c|c|c|}
\hline & $\begin{array}{c}\text { malignant } \\
23\end{array}$ & $\begin{array}{c}\text { benign } \\
7\end{array}$ & $\begin{array}{c}\text { Total } \\
30 \\
(100.0 \%)\end{array}$ \\
\hline $\begin{array}{l}\text { 術前と同職または } \\
\text { 同程度の学働 }\end{array}$ & 8 & 7 & $\begin{array}{c}15 \\
(50.0 \%)\end{array}$ \\
\hline 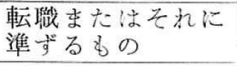 & 8 & 0 & $\begin{array}{c}8 \\
(26.7 \%)\end{array}$ \\
\hline 休 倳 & 7 & 0 & $\begin{array}{c}7 \\
(23.3 \%)\end{array}$ \\
\hline
\end{tabular}

表16 Operative mortality

\begin{tabular}{l|r|r|r}
\hline \multicolumn{1}{c|}{ Authors } & & $\begin{array}{c}\text { No. of } \\
\text { cases }\end{array}$ & $\begin{array}{c}\text { Mortality } \\
\%\end{array}$ \\
\hline Levitsky & 1953 & 27 & 18.5 \\
Johnson & 1956 & 17 & 18.0 \\
De Campos et al. & 1964 & 11 & 18.2 \\
Bracci & 1967 & 146 & 12.5 \\
Nedelec & 1967 & 37 & 8.1 \\
Staehler & 1967 & 25 & 4.0 \\
柏井5 & 1974 & 44 & 6.8 \\
\hline
\end{tabular}

の手術は，近年になり次第に注目されるようになり，そ の成績も向上しつつある.そして術後の完全な社会復州 が期待できるよらになつた。しかし，第1篇で述べたよ らにその術後成績は必ずしも満足すべきものでなく，手 術手技上飞も問題となる点が残されている，一般に回腸 導管については，術後成績の詳細な検討が多くの諸家に よりなされている，これに反し直腸膀胱術にはこのよう な文献に乏しいのが実情である，ここでは，筆者らの得 た成績をるとに以下の諸点について検討することにす る.

\section{1. 手術の適応と患者の撰択}

この術式は術後の社会復㷌が期待される反面, 手術操 作がやや難かしいといらことから，一般に高令者はその 適応から除外されている，筆者らはこのような考方方に とらわれず，たと完60才を超えていても，身体の諸機能 に決定的な障害のない限り, あえて手術を行なつた. 手 術死亡と考光られるものは 3 例（ $6.8 \%$ )であつたが， 患者の年令は 70 才代 1 人，40才代 2 人で, 必らずしも高 年令層に限られていない， 3 例とも膀胼腫瘍で, 膀胱全 摘除を施行している。これらのことから, 本手術の適応 年令は画一的には決められず，原疾患の種類と身体的情 況によつて決定されるべきものと考觉る、筆者らの経験 からでは, 膀胱全摘除を併用する場合は70才以下が適応 年令であると考兄られる。なお，諸家により報告されて

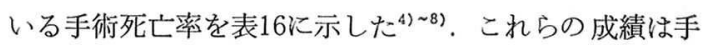


術手技, 術中, 術後管理の進歩により, 今後さらに向上 するものと思われる.

1 力月以後の死亡は10例で, それらの死亡時期は術後 4 カ月より 5 年である。これらの症例はすべて膀胱腫瘍 で, 摘除不能の 2 例を除いて, 他は膀胼全摘除術を施行 し根治を期待したにもかかわらず，その死因はすべて腫 瘍死であつた。他方, 良性疾患（難治性尿道狭窄, 膀胱 胵瘦）に行なつた症例 7 例は，現在すべて生存中で（術 後 1 年 2 カ月〜 7 年 8 力月), 例外なく社会復㷌を達成し ている.

以上の事実から，この術式の最終目的が，患者のより 完全な社会復帰にあるとすれば, 筆者らが行なつてきた 膀胱全摘除術の適応時期そのものに問題があるように思 われる。

\section{2. 術後の上部尿路感染と尿管腸吻合術}

上述したよらに, 術後の合併症（早期・晚期ともに） の中で最も高い頻度を示すものが腎孟腎炎である. 回腸 導管に拈汓る術後の急性腎孟腎炎については, Minton $ら^{99}$ の発生率40\%（40例中16例）と云う報告もみられる が，他の多くの報告を総合すれば，その発生率は術後早 期では低く，ほぼ $2 \%$ 3\%前後で，その後日時ととも に增加し15\%〜20\%に打よぶとされる ${ }^{10111)}$. これを筆者 らの得た成績と比較すれば, 直腸膀脱では術後早期, 晚 期ともに明らかに高い発生率を示している.これが直腸 膀脂の術後経過の特徴であり,この術式の最大の弱点と されるところである.

図 1 は術後の pyelonephritic attacks の頻度を, さら に詳しく示したものである. 1 回の attacks るみられな かつた症例は術後 1 力月以内では41例中 25 例 $(61.0 \%)$, 術後 1 年以内では36例中 20 例 $(55.6 \%), 1$ 年以後では 26 例中17例 $(65.4 \%)$ となつている、実際にpyelonephritic attacks が頻発（1 年に 3 回以上）し，患者本人な らび に医師が困惑した症例 は 1 年未満のもので 36 例中 6 例 $(16.7 \%), 1$ 年以後のもので26例中 4 例 $(15.4 \%)$ であ つた。これら frequent attacks をみる症例は尿管・腸吻 合の成績が poor (IVP で) の群に多く，このような場 合：罹患側の腎機能は低下するこの意味で尿管腸吻合 術の成否は術後の上部尿路の状態を左右するものと考え られ，必然的に吻合術式の撰択が問題となる.この点に ついて従来の文献をみれば、尿管・腸吻合術式としては Kerr-Colby 法によるもの ${ }^{712)}$, submucosal tunnel 法に よるもの ${ }^{13) 14)}$ や粘膜・粘膜吻合法によるもの ${ }^{5115)}$, その 他 ${ }^{16)}$ 術者の好又により行なわれているが，それらの術後
IVP による詳細な追跡はなされていない，前述のよう に悪化率の点からみた筆者らの成績では粘膜・粘膜吻合 法 (Cordonnier 法) が最もすぐれ，ついで submucosal tunnel 法 (Goodwin法), seromuscular folding法の順であ つた (Kerr-Colby 法は吻合回数が乏しく, 比較の 対象 にならなかつたが，筆者らの乏しい経験からでも，必ら ずしも，すぐれた吻合法とは云えない，逆に，腸・尿管 逆流現象の発生率は粘膜 · 粘膜吻合法が高く, 他の二法 はともに低い。これらの術後し線所見と pyelonephritic attacks の発現頻度の関係を検討したが，その結果はす でに述べたとおりである。これを要約すれば，(1) frequent pyelonephritic attacksをみる症例は術後 IVP の成績が poor であるものが多い. 特に術後 1 力月以後 では pyelonephritic attacks の発現頻度はIVP の成績 と相関する．（2）腸・尿管逆流現象の有無は, 術後 1 年以後になると pyelonephritic atlacks の発現に関係し ない，の 2 点があげられる。これらの事実は，（遊離） 直腸膀胱の術後の上部尿路感染は, 腸・尿管逆流よりも 移植部尿管の狭窄による尿流停滞が上り重要な原因と考 えられる.この意味で, 逆流防止操作を併用した ureterocolic anastomosis が今一つその確実性を欠く現在, 筆者らは主として尿管の移植に粘膜・粘膜吻合法を用い ている. Bracci ${ }^{7)}$ も術後の再発性腎盂腎炎の主因は逆流 よりもむしろ尿の通過障害とみなしている．ただ彼の行 なつている吻合術式は粘膜・粘膜吻合法でなく，KerrColby 法である点は理解できない.

3。術後の腎機能ならびに酸塩基平衡

一般に尿管・腸吻合術の結果が良好である場合, 術後 晚期になつても腎機能の低下はみられない，前述のよう に術後 BUN,血清クレアチニン值の異常を示したものは follow up できた症例中10\%前後で，乙かもその大部分 は軽度の上昇を示したにすぎない。両側尿管移植が失敗 し, bilateral progressive hydronephrosis のため, 止むな く他の尿路変向術に再変向したものは 1 例のみであつ た。

Base excess については. 残念ながら一部の症例しか follow up できなかつたが 明らかに臨床症状を伴なつ た hyperchloremic acidosisは3 例 ( 7.3\%) であつた. その 3 例に共通した点をあげれば（1） acidosis を增悪 させる何らかの誘因をもつている（第1例は subileus， 第 2 例は急性腎孟腎炎, 第 3 例は両側水腎症に上る腎機 能低下)，(2) 何机も一過性に経過し，アルカリ剂投与 により回復した,の 2 点であつた. 術後 base excess の 
低下を認めながら，無症状に経過する症例も一部に認め られたが，持続的にアルカリ剤投与を必要とする症例 は, むしろ例外である。

腸管を利用した尿路変向術後における腎機能について は, その検查法自体に種々の問題を有する場合が多いう 光, その評価には術後長期間の follow up が必要と考光 られ，安易な結論はつつしまねばならず，これらの点に ついて今後の検討が望まれる.

4. 術後の排尿機能ならびに排尿愁訴について

術後の排尿機能については, 前述のように良好で, 一 定の頻尿期を経て, まもなく尿回数は固定する（昼間 5 $\sim 12$ 回, 夜間 $1 \sim 5$ 回).尿の禁制保持も良好で, 適応を 誤つた 1 例を除いて失禁を認めていない，なた，残尿も $30 \mathrm{ml}$ 以下で問題にならない，これら排尿機能の上で, 3 術式 (前方型, 倒方型, 後方型の) 間に何らの差異も 認めなかつた。

次に，排尿愁訴であるが，無視できないるのに夜尿症 がある：前述のように follow up できた症例の約半数 (51.5\%) は夜尿症を経験し，そのうち5例 $(15.2 \%)$ は毎夜遺尿を認めた，遊離直腸膀脱にお沙子夜尿症につ いては，従来よりその記載はみられるが，これを問題視 している文献は少い. Whitmore ${ }^{17)} は$ Mauclair 手術に 拈ける認むべき愁訴として夜尿症をあげている，その発 現機序について, Colon の切断, 分離によつて発生する rectosigmoid の neurogenic dysfunction によるものか, または夜間の overflow incontinence によるものと説明 している．筆者らの得た直腸膀胱内压曲線からみれば, 直腸膀胱は正常の膀腅に比し, より強い自働性を有する ように思われ，この点からみれば下部結腸を切断分離 し，その容量を限定することは夜尿症の発現を促進させ ることになるものと考兄られる。な拉，直腸膀脂の夜尿 症に対して，筆者らは Imipramine（商品名トフラニー ル・藤沢）25mg〜50mgを就床前に投与したところ有効で あつた。

その他の愁訴としては，1例で排尿前後の強いテネス ムを, 他の1例で二段排尿をみた。前者の症例では術後 小骨盤腔内の膿瘍形成が, 後者では直腸膀胼の異常屈曲 (kinking) が原因であつたと思われる. 直腸膀胱の術 後の異常变位や屈曲は, このように排尿愁訴の原因々な るばかりでなく，吻合された尿管を不自然にけん引，圧 排する場合も考劣られる。それゆえ，筆者らは遊離した 直腸・ $\mathrm{S}$ 状状結腸をその頂部で, 後壁腹膜に固定するこ とを心がけている。

\section{5. 術後の排便機能について}

術後の排便機能を論ずる場合, 以上の 2 点が問題とな る.すなわら（1）会陰部肛門管を新しく作成 (sigmoid pull through) して, どの程度までの排便機能が得られ るか?，（2）得られた排便機能の成績から，肛門括約 筋内結腸瘦の位置により分類されている三術式間に優劣 をつけ得るか?である.この意味で, 術後の排便機能を 一定の評価方法に従つて追究する必要が生ずる.しかし 排便機能というものが多数の因子よりなり立つているた め, その評価には困難が多い。

近年, この種の研究は直腸肛門外科, 特に鎖肛, 先天 性巨大結腸症や直腸癌（括約筋温存術式のとき）の術後 の重要な問題としてとりあげられてきた．排便機能評価 法は，現在いろいろと多く，まだ統一された方法はない が, 直腸肛門奇型術後の排便機能評価法として, 現在, 比較的広く用いられているものに Kelly code ${ }^{18)}$ があ る.これはコンチネンス，下着污せん（staining），括約 筋収縮力 (sphincter squeeze) の3 項目と，それにレ線 学的検査 (cinedefecography) を併用し，それぞれの parameters に点数を与え半定量化したものである。 た, より, 客観的, 数量的評価法として括約笳収縮力検 查, 直腸肛門管内圧の測定も試みられている ${ }^{19220)}$. 筆者 らの用いた評価法は定量化は試みておらず，むしろ，里 村 ${ }^{21)}$ それに類似している，ここに，成績を要約すれば 以下のとおりである.

（1）術後の排便機能獲得には 3 力月〜 6 力月を要す る.

（2）䔬便の通過感覚, 糞便性状の識別, 排便開始を 促がす予告感, 抑制力の順に獲得される.

（3）排便の断続化（1 回の排便動作で下部結腸の内 容をすべて出しきれないために起る）は，一部の症例を のぞいて,いつまでも残る。

（4）排便開始を促がす刺激 (defecation stimuli) に は3 種ある。

（5）排便予告感, 抑制力の点から後方型手術が他の 術式に比し優れている.

（6）排便機能の良好な症例では注腸による直腸・ 肛門管の造影で, 明膫な“くびれ” angulationをみとめ る.

注腸レ線造影における新肛門管上端の angulationは, 直腸, 肛門手術後における, いわゆる anorectal angulation $^{22)}$ ，に相当するもので，これは puborectal sling によ り形成されるものと考兄られる. Stephens ${ }^{23)}$ 以来, こ 
の puborectal sling を損傷しないことが, 術後の排便 機能獲得の上に重要であることは周知の事実となつてい る.筆者らも，すでに述べたように， sigmoid pull through に際して，直腸に挿入せる手指で puborectal sling を触れ，確認した上，その内側を注意深く剝離するよう にしている.この場合，直腸壁またはsling を損傷せ ず， S 状結腸端を retrorectal に pull through させるこ とは, 他の 2 術式に比して難かしいが, puborectal sling を最も効果的に利用する点では, 後方型手術が, 上り適 した術式であると考えている.

木村 ${ }^{24)}$ は puborectal sling を含む, 直腸周囲の挙肛 筋は，単に䔬便の括約作用を有するばかりでなく，排便 の神経刺激に対する receptor としても重要で, これら 諸筋の温存を重ねて強調している。このことは, 術後の natural rectal sensation の獲得に後方型手術が優れてい るという Bracci や筆者らの成績を理解する上に有利な 情報と思われる。

6. 手術の staging について

Staehler は安全を期して手術を 3 段階に分け好成績を 怙さめている。これは直腸膀脂形成の前後に横行結腸瘦 の造設と閉鎖を行ならものである. 3 stages に行なつた 筆者らの症例はただ 8 例にすぎず，その有用性について は明らかでない、しかも，横行結腸㾇の造設と閉鎖とい ら操作は，患者ならびそ医師にとつて無視できない負担 があり, また, 進行の可能性を有する膀脂腫瘍に対して 根治手術の時期を失ならことにもなる.これらの理由か ら現在，筆者らは 1 stage 法で充分と考えている.

次に肛門部手術操作の staging の問題にふれる. 会陰 部に引き出した $\mathrm{S}$ 状結腸端を 1 次的に処理し，ただちに 腸粘膜と肛門部皮膚との縫合を行なうことは, 粘膜 の extroflexion あるいは断端部え死に伴なら新肛門の狭窄 など合併症をみることが多いと予想される，この意味

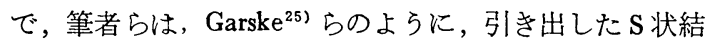
腸端を, まず wet anusの状態に治癒させてから，二次的 に過不足のないよう脱出部 S 状結腸を切除することして いる.これにより肛門部合併症は可及的に避けられるも のと考光る.

\section{まとめ}

過去 8 年間に肛門括約筋内結腸瘦を併用せる直腸膀脂 術44例を経験し，その成績を述べた。

（1）手術死亡は 3 例 $(6.8 \%)$ で何れも悪性疾患に みられた. 1 カ月以後の死亡は10例を数えるが，そのす ベては腫瘍死であつた。
（2）術後合併症のらちで，早期，晚期とも最も頻度 の高いものは腎監炎である. 明らかな臨床症状を伴つ た hyperchloremic acidosis は 3 例 ( 7.3\%) で, 何れも 一過性であつた.

（3）術後の IVP の推移ならびに腸尿管逆流の有無 を検討し，尿管・腸吻合術の成績を述べた。（遊離）直 腸膀胼の術後の上部尿路感染は, 腸尿管逆流よりも, 移 植部尿管の狭窄による尿流停滞がより大きな原因になる と考兄られる．この意味で尿管吻合術式としては粘膜・ 粘膜吻合法が安全である。

（4）術後の排尿機能は，ほぼ良好であつた．ただ排 尿愁訴として夜尿症を $51.5 \%$ (15.2\%は連日の夜尿) に 認めた。

（5）術後排便機能獲得の経過を述べた．排便機能の 面からみれば, retroanal (rectal) sigmoid pull through が他の術式より有利である. sigmoid pull through に際 して, puborectal sling の損傷を可及的に避けることが 肝要である.

（6）術後患者の半数（30例中15例）が術前の生活環 境に復㷌し得た。良性疾患群では, 現在まで全例に社会 復帰が果されている。

第 2 篇の稿を終えるに当り，多大の助力をいただいた 下記の諸氏と諸機関に感謝します

（敬称略，㮌不同）

朝野 登, 竹谷 弘, 久保田行男 (大阪厚生年金病院 外科, 麻醉科), 小林永二, 木下勝博, 結城清之, 八竹 直, 永田 肇, 森 義則 (元大阪厚生年金病院泌尿器科 在籍者）植田 隆, 藤野俊夫（大阪市立小児保健センタ 一外科) 岡本英三（兵庫医科大学外科）

大阪大学医学部泌尿器科教室

神戸大学医学部少

大阪市立大学医学部 "

大阪市立十三市民病院泌尿器科

姫路日赤病院泌尿器科

本論文の要旨は第23回日本泌尿器科学会中部連合地方 会において報告した。

\section{文献}

1) Staehler, W. und Oswald, K.: Urol. int., 22, 91, 1967.

2）石山修二：日泌尿会誌，47, 285, 1956.

3) 林田重昭, 桐山菑夫, 酒徳治三郎: 泌尿 紀 要, 18, 802, 1972.

4) Levitsky, V.: Am. J. Surg., 85, 91, 1953. 
5) Johnson, T.H.: J. Urol., 76, 380, 1956.

6) De Campos Freire, J.G. and De Goes, G.M.: quated by Staehler, W.: Langenbecks Arch. klin. chire., 311, 333, 1965.

7) Bracci, U.: Urol. int., 22, 1, 1967.

8) Nédélec, M.: Urol. int., 22, 47, 1967.

9) Minton, J.P., Kiser, W.S. and Ketcham, A.S.: Surg. Gynec. Obstet., 119, 541, 1964.

10) Cordonnier, J.J. and Bowles, W.T.: in Urology, Compbell, M.F. and Harrison, J.H., 3rd ed. p. 2321, Saunders Co., Philadelphia, 1963.

11) Schmidt, J.D., Hawtrey, C.E., Flocks, R.H. and Culp, D.A.: J. Urol., 109, 210, 1973.

12）緒方二郎，池上奎一，川野四郎，西正夫 : 西日 泌尿, 33, 292, 1971.

13) Dorsey, J.W. and Barnes, R.W.: J. Urol., 85, 569, 1961.

14) Culp, D.A. and Flocks, R.H.: J. Urol., 95, 334, 1966.
15) Stonington, O.G. and Eisman, B.: J. Urol., 76, 74, 1956.

16)柏井浩三, ほか：泌尿紀要，18，462，1972。

17) Whitmore, W.F. Jr.: The ureter, ed. by $H$. Bergman, p. 625, Hoeber, Harper \& Row Publishers, New York.

18) Stephens, F.D. and Smith, E.D.: Ano-rectal malformations in children, p. 353, year Book Medical Publishers, Inc., Chicago, 1971.

19) 田中正和：日大医誌，26，14，1967.

20）長崎 彰, 池田恵一, 大神浩, 水田祥代 : 日 小外誌, 9, 263, 1973.

21）里村紀作: 手術, 24, 297, 1970.

22) Kelly, J.H.: J. Ped. Surg., 4, 538, 1969.

23) Stephens, F.D.: Med. J. Australia, 1, 202, 1953.

24) 木村忠司, 里村紀作 : 手術, 21, 256, 1967.

25) Garske, G.L. et al.: J. Urol., 84, 322, 1960.

(1974年 5 月 16 日受付) 